\title{
Application Of Analytical Hierarchy Process (AHP) And Concept, Assessment, Demonstration, Manufacture, In Service, And Disposal (CADMID) In The Military Procurement System
}

\author{
Indonesia Defence University \\ DOI: 10.29322/IJSRP.11.10.2021.p11865 \\ http://dx.doi.org/10.29322/IJSRP.11.10.2021.p11865
}

Rujito Dibyo Asmoro, Suharto, Mitro Prihantoro, Cecep Hidayat, Purnomo Yusgiantoro

\begin{abstract}
State defence is all efforts to defend the sovereignty of the state, the territorial integrity of the Unitary State of the Republic of Indonesia, and the safety of the entire nation from threats and disturbances to the integrity of the nation and state. In general terms, the state defence system is a universal defence system that involves all citizens, territories, and other national resources, and is prepared early by the government and is carried out in a total, integrated, directed, and continuous manner to uphold state sovereignty, territorial integrity, and safety of nation from all threats, and to achieve all that requires state defence management. State defence management is all activities at the strategic and policy level which includes planning, implementation, supervision, and control of the national Defence. One part of the national defence management system is the procurement. Armament (weapon systems) are the most important part of a national defence system. By having formidable weapons, national development can be carried out safely, orderly, and smoothly. In other words, a strong national Defence system has a deterrent effect for parties that will disrupt or create instability within the country. The problem of selecting the country that makes the main weapon system equipment is also one of the important variables in making decisions on the procurement of goods and services in a military logistics cycle. The selection of weapons-producing countries can be done using an analytical hierarchy process (AHP) approach combined with CADMID. AHP is a tiered process that starts from setting state goals, determining criteria and sub-criteria until alternative selections are obtained. The CADMID will complete the final results of the AHP which is poured into a blueprint starting from the concept, then an assessment of the concept is carried out, the results of the assessment are then demonstrated (demonstration), and after the results of the demonstration meet the desired requirements then will continue with the manufacturing stage. If the manufacturing results pass several required tests, a weapon system will enter the in-service phase, and after being operationalized for a certain period, the weapon system will enter the disposal phase. CADMID is a lengthy process with a period of 25 to 30 depending on the country's ability to update its percentage system.
\end{abstract}

Index Terms- AHP, CADMID, state Defence, Defence procurement, manufacturing country

\section{PREFACE}

$\mathrm{W}$ ithin the framework of the Indonesian National Defence Strategy, the Ministry of Defence and the TNI have drawn up a forcebuilding plan by adding, rejuvenating, and modernizing combat equipment in a planned manner, based on operational considerations, ${ }^{1}$ which are compiled in the so-called Minimum Essential Forces (MEF).

Based on the national Defence strategy, the determination of the manufacturing country in the procurement of TNI's armaments must be based on some considerations of operational and technical needs. Consideration of operational needs adhering to the principles of consistency, sustainability, and interoperability following the operational strategy based on Indonesia's geographic constellation.

Operational and technical aspects are the main considerations of any TNI armaments procurement because they affect changes in operational strategies and tactics that rely on joint operations involving three services; the army, navy, and air force. The importance of analyzing each of these technical consideration criteria encourages researchers to carry out research using the Multi-Criteria Decision Making (MCDM) method, namely CADMID and AHP to measure the qualitative assessment of two different methods is faced with the consideration of operational needs to support Indonesia's Defence strategy so that at the end, alternative priorities for the manufacturing country can be determined in the procurement of TNI's Armaments.

CADMID has a standard structure that is carefully compiled from the process of determining the user's needs to the process of disposal. The CADMID structure consists of Concept, Assessment, Demonstration, Manufacture, In-Service, and Disposal. Based on the CADMID approach, it can be seen that the series of Defence procurement processes should sustainably take place even though in reality there are gaps between stages. This can be seen from the realization of technical specifications that are driven by the user's

\footnotetext{
${ }^{1}$ Kementerian Pertahanan, Strategi Pertahanan Indonesia, Jakarta: Kemhan, 2014, h. 12.
} 
operational needs, hampered by bureaucratic complications between the Ministry of Defence and the TNI as requirement generators, and at the same time dealing with the procurement that compromises technical specifications. This shows that there is a gap between needs and the procurement process.

The theory that supports this pattern is grounded theory, even so among the followers of grounded theory, there is never an agreement between them about its definition. For this study, Punch's (1998) statement is considered relevant "... In my opinion, grounded theory is best defined as a research strategy whose purpose is to generate theory from data....; the theory will therefore be grounded in data....". ${ }^{2}$ For this research to be properly structured and well-constructed, modeling is needed to illustrate this. Figure 1, is a model developed by the researcher to visualized the construction of ideas as Comprehensive Strategic Thinking on Defence Acquisition (CoSTDA).

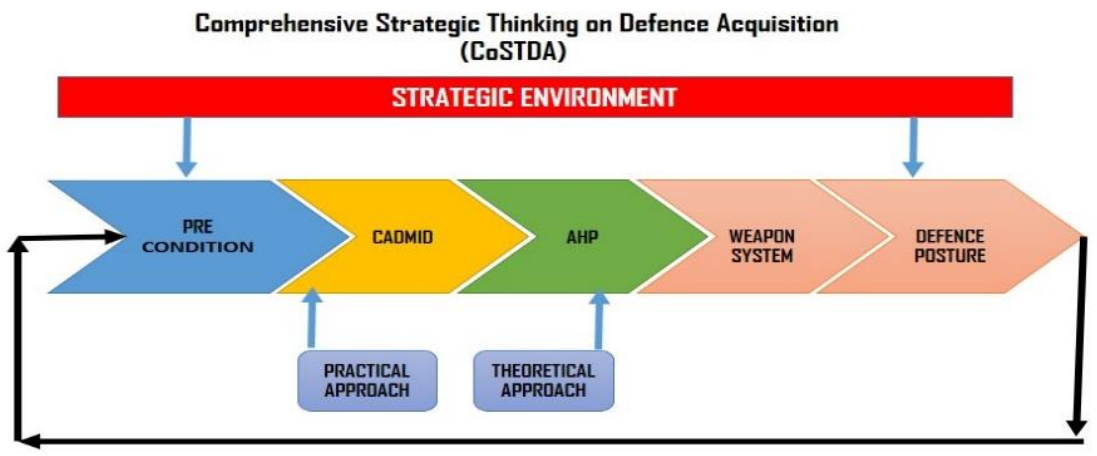

Figure 1. Comprehensive Strategic Thinking on Defence Acquisition (CoSTDA) Model Source: Processed by Researchers, 2020.

The AHP theory was developed in 1970 by Thomas L. Saaty. AHP is an MCDM method as a structured technique to assist the community in determining the priority of several criteria by conducting pairwise comparisons of each criterion. ${ }^{3}$ Unlike other MCDM methods, AHP is a decision support system that decomposes a complex multi-factor problem into a hierarchy, where each level is formed from specific elements that are not related to each other. The main tool of AHP is a functional hierarchy with the main input being human perception. The existence of a hierarchy allows solving complex or unstructured problems in sub-problems, then arranging them into a hierarchical form. The stages in working on AHP include identifying problems, decomposing problems by compiling a hierarchical structure, implementing comparative judgments, performing synthesis of priority, and measuring consistency ratio. Whilst CADMID for this research referred to smart acquisition processes to achieve a product (armaments) with effective and efficient effort. This long and detailed process was aimed to be effectively spending the allocated budget and to reduced risk. ${ }^{4}$ In particular circumstances, CADMID helps decision-makers in the Ministry of Defence to be well informed concerning the Defence procurement cycle by referring to classical management cycles such as planning, organizing, actuating, and controlling. ${ }^{5}$

\section{RESEARCH METHODS}

This study uses a mixed-method research method, which combines the CADMID as a qualitative approach on the one hand and AHP as a quantitative approach on the other. (Cresswell, 2018). This method is used sequential exploratory design, but each is explored independently to answer the same problem formulation, namely how to determine the country that produces armaments for TNI at the initial stage, supporting with criteria and priorities on the following stages. This research draws data from resource persons (experts) within the Ministry of Defence and the TNI in charge of the procurement of goods and services, especially armaments.

\section{RESULTS OF ANALYSIS AND DiSCUSSION}

\section{Data processing with CADMID}

The analytical method used in this research is CADMID, which is a structured procurement mechanism with phases so that the procurement of armaments gets a product that is in line with the buyers' expectations. CADMID is used to define criteria and is described further.

\footnotetext{
${ }^{2}$ Punch, K. F. (1998) in Shahid N Khan (2014), "Qualitative Research Method: Grounded Theory”, International Journal of Business and Management, Vol. 9, No. 11; 2014, p. 227

3 Thomas L. Saaty, Decision Making with the Analytic Hierarchy Process, Pennsylvania: University of Pittsburg, 2008, pp. 83-98.

${ }^{4}$ Crown, The Acquisition HandbookI, Tactica Solutions Limited, 2002. Edition 4 January 2002, pp. 4-5

${ }^{5}$ Samadi (et al), Implementation of The Concept and Theory of Management Functions in Efforts to Improve Quality, International Journal of Economic, Business and Accounting Reseacrh (IJEBAR), Volume-Issue 2, 2020 (IJEBAR), 2020, p.356
} 
A concept is a user's requirement document (URD) that contains information related to the wishes of the buyer. If you take an example of aircraft procurement, the URD may contain technical specifications, maneuverability, complete communication systems, avionics systems, radar system, weapon systems, and so on. URD will of course have implications on prices, in other words, the more sophisticated systems you put on your list, the more budget you may spend. Thus, a concept has a significant impact on the end-product and budget

Assessment is a document creation mechanism that contains the system required by users (SRD) armaments to be made. SRD is a document to control what has been stipulated in the URD. Assessment is manifested in price and quality criteria. Assessment is carried out continuously to get quality armaments commensurate with the price paid by the user.

The Demonstration is a progressive effort to eliminate risks and improve performance targets, ensuring that the relationship between SRD and URD can be maintained by entering into contracts to fulfill SRD and demonstrating integrated production capabilities.

Manufacture is the production process for armaments under what is stated in the URD and SRD. In this manufacturing stage, three main components are very important to get attention, namely the suitability of technical specifications, costs, and time. The relationship between criteria in the context of manufacture is very clear, where there are criteria for price, quality, and delivery as well as local content.

In-Service, it is intended that the armaments have gone through the delivery phase and have been received by the user, where at this stage everything related to maintenance, repair, and improvement of the Armaments capability in the future after the operation of the Armaments. The In-Service stage is represented by the criteria for price, delivery, and technology transfer. Armaments maintenance and repairmen of armaments have implications for price. The improvement of the defence equipment capabilities, which is recalibrated to meet operational needs has implications on technology transfer criteria.

Disposal is a mechanism in which armaments are no longer meet operational requirements. Some of the options for disposal include deletion from the state inventory list or offered to other parties who require an agreed sale and purchase scheme. The agreement between the two parties has implications for the criteria of price, delivery and technology transfer. Disposal aspects of this study are not part of the research criteria, this is because the defence equipment referred to in this study is a new procurement with a very long lifetime.

From the overall CADMID analysis above, five criteria are determined which are considered to be followed up and quantified using the AHP method, namely price, quality, delivery, local content, and transfer of technology.

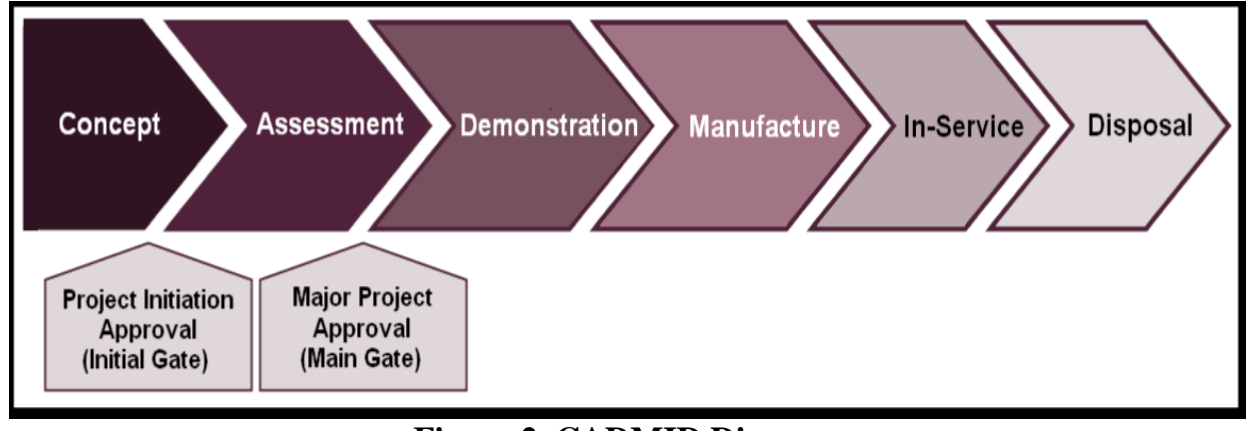

Figure 2. CADMID Diagram

Source: Processed by Researchers, 2020.

\section{DATA PROCESSING WITH AHP}

The data processing method using AHP theory allows researchers to get the overall priority value or Total Priority Value (TPV) of the technical criteria as a priority to determine the country that makes TNI's armaments. AHP method decision-making requires absolute consistency of variable weights in decision making. The AHP hierarchy diagram is prepared based on the number of criteria and subcriteria obtained from the CADMID cycle and will be analyzed using the AHP method. 


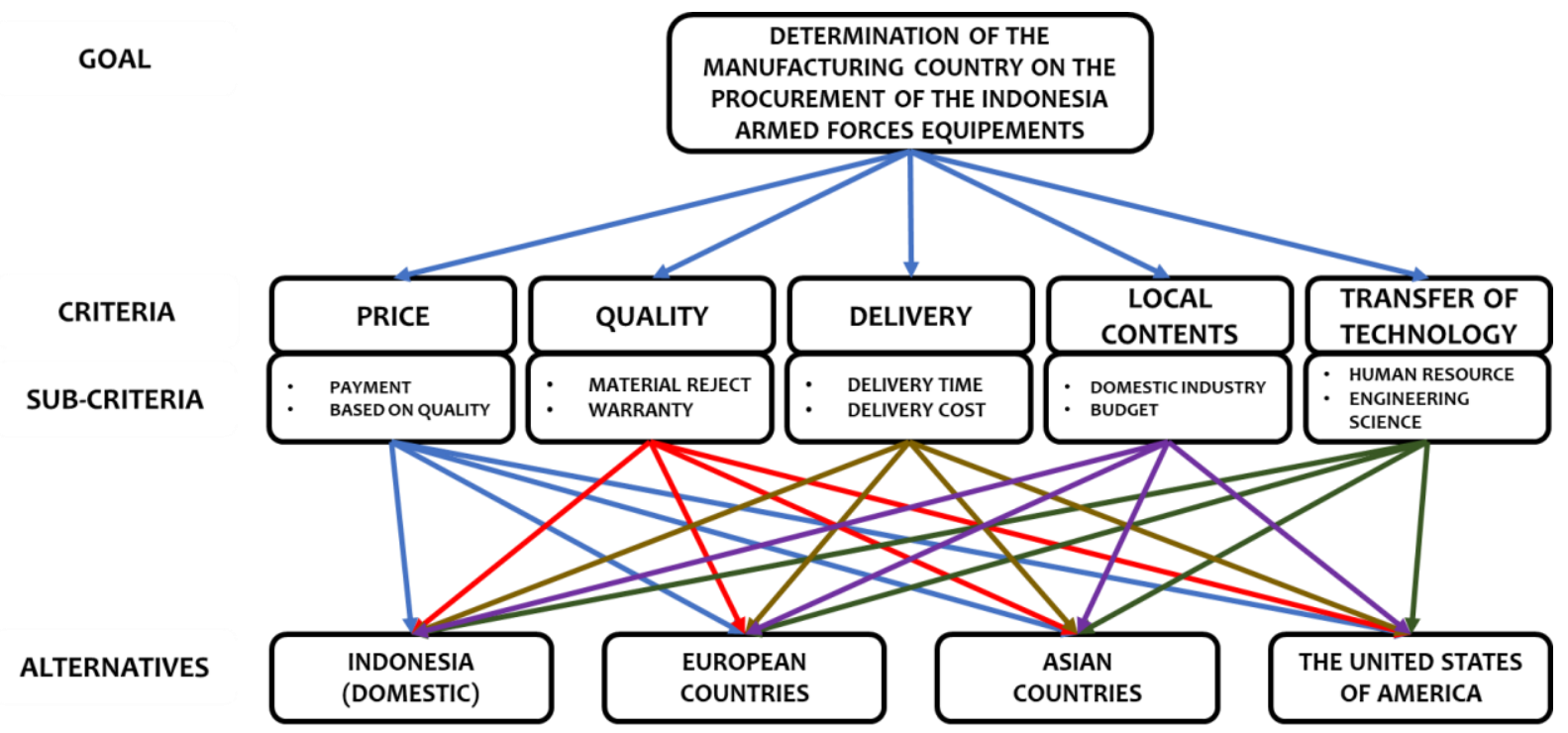

Figure 3. Hierarchy Diagram

Source: Processed by Researchers, 2020.

The components used as criteria in making the hierarchy diagram in Figure 3. above consist of five technical considerations in the procurement of TNI armaments, namely price, quality, delivery, local contents, and transfer of technology. The data obtained from 9 respondents through a questionnaire is used to process data that takes into account the criteria for determining the priority of the selected country from 4 alternatives, namely Indonesia (Domestic), Countries in Europe, Countries in East Asia, and the United States as the making country of TNI's armaments to achieved consistency, sustainability, and interoperability. The AHP step involves estimating the priority weight of a set of criteria, sub-criteria, or alternatives from the square matrix used in the pairwise comparison $A=\left[a_{i j}\right]$, where the weight values must be positive, and if the pairwise comparison policy is completely consistent then inverse comparisons are made from this value, for example: $\mathrm{a}_{\mathrm{ij}}=1 / \mathrm{a}_{\mathrm{ij}}$ for all $\mathrm{i}, \mathrm{j}=1,2,3, \ldots, \mathrm{n}$. Furthermore, the final weighting of factor ' $\mathrm{I}$ ' is normalized, as follows:

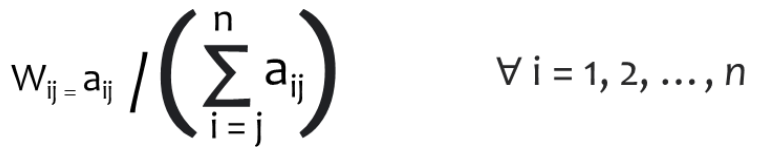

Tabel 1. Saaty Comparison Scale

\begin{tabular}{|l|l|}
\hline 1 & Criterion A/Alternative A is Equal importance as Criterion/Alternative B \\
\hline 3 & A is Somewhat more important than B. \\
\hline 5 & A is Much more important than B. \\
\hline 7 & A is Very much more important than B. \\
\hline 9 & A is Absolutely more important than B. \\
\hline $2,4,6,8$ & When in doubt between two values that adjacent \\
\hline
\end{tabular}

Source: Decision Making for Leader, Saaty, TL, 1994.

Here $w_{i}$ indicates the weight of the element $C n$ while $a_{i j}=w_{i} / w_{j}$ is a number that indicates the strength of $C_{i}$ when compared to $C_{j}$. The $A_{i j}$ number matrix is represented by $A$ as follows: 


$$
A=\left[a_{i i}\right]=\left[\begin{array}{cccc}
1 & W_{1} / W_{2} & . . & W_{1} / W_{n} \\
W_{2} / W_{1} & 1 & . . & W_{2} / W_{n} \\
: & : & . . & : \\
W_{n} / W_{1} & W_{n} / W_{2} & . . & 1
\end{array}\right]=\left[\begin{array}{c}
A^{1} \\
: \\
A^{1} \\
A^{n}
\end{array}\right]
$$

Furthermore, it is examined whether the pairwise comparison based on the policy is still within the stipulated limit or not. Measuring natural consistency or deviation from consistency is called a consistency index ( $\mathrm{CI}=$ Consistency Index $)$ which is defined as follows:

$$
\mathrm{Cl}=\frac{\lambda_{\max }-\mathrm{n}}{\mathrm{n}-1}
$$

Table 2. Data Collection and Geomen Calculation

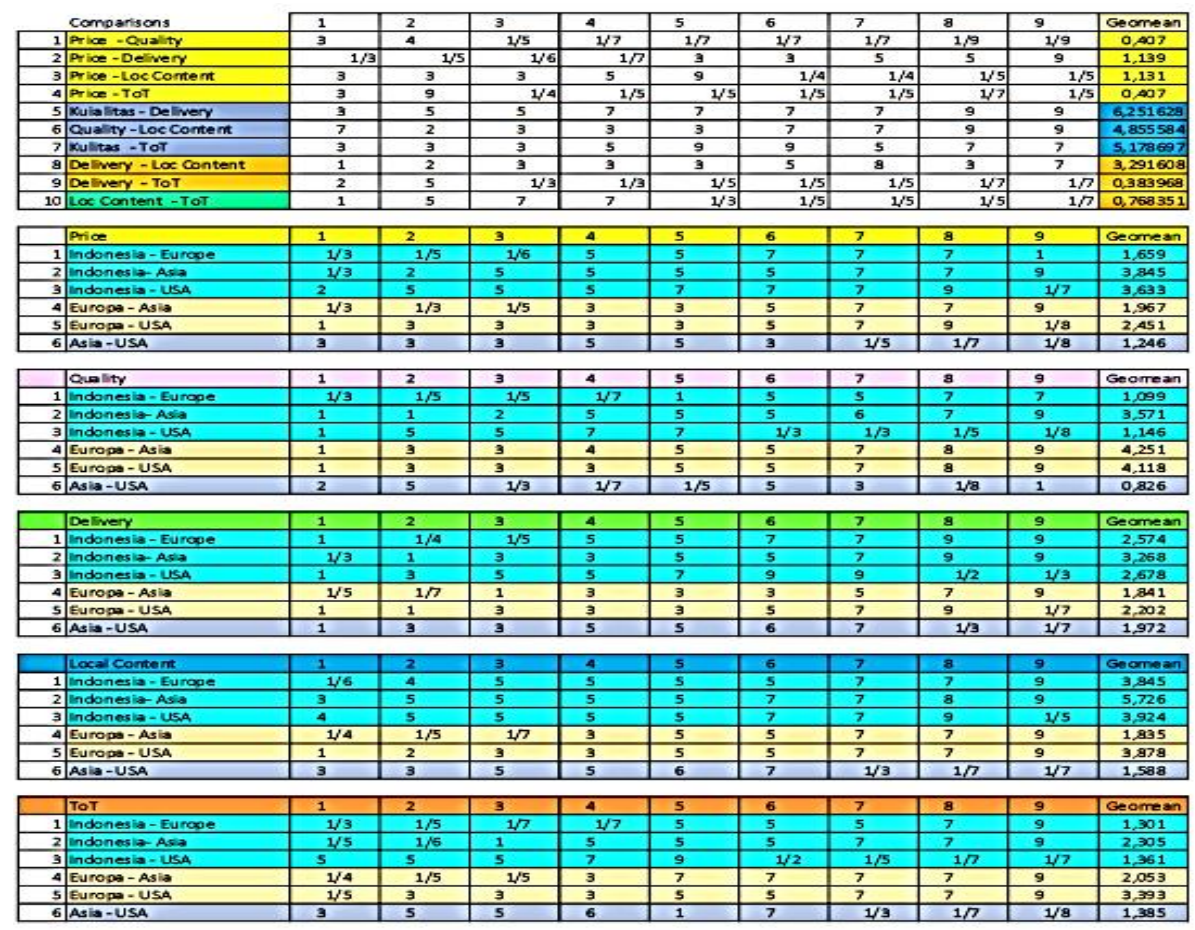

Source: Processed by Researchers, 2020.

The consistency index of a randomly generated inverse comparison matrix scale 1 to 9 , with inverse comparison results, for each matrix size called the Random Index (RI) is shown in the following table:

Table 3. Random Index

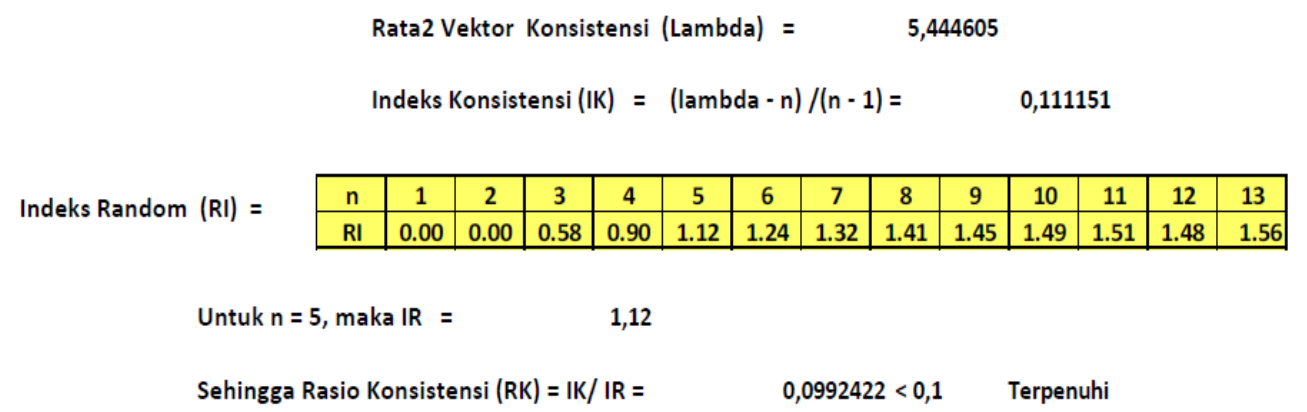

Source: Decision Making for Leader, Saaty., T.L. 1994 and processed by Researchers, 2020.

This publication is licensed under Creative Commons Attribution CC BY. 
Pairwise comparisons are made of the five technical criteria considered in the TNI defence equipment procurement process. Researchers distributed paired comparison questionnaires to 9 TNI officers who have responsibility and experience in the TNI defence equipment procurement work unit. Comparative assessment is carried out using the Saaty's Comparison Scale. Then the score is calculated for each criterion from the experts using the method of calculating the average value using geometric multiplication (Geometric Mean) and the value of each criterion is obtained as shown in Table 4.

Table 4. Pairwise comparison of Technical Criteria

\begin{tabular}{|l|l|l|l|l|l|l|}
\hline CRITERIA & PRICE & $\begin{array}{l}\text { QUALIT } \\
\text { Y }\end{array}$ & $\begin{array}{l}\text { DELIVER } \\
\text { Y }\end{array}$ & $\begin{array}{l}\text { LOCAL } \\
\text { CONTENT }\end{array}$ & ToT & $\begin{array}{l}\text { Eigen } \\
\text { Value }\end{array}$ \\
\hline PRICE & $\mathbf{1 , 0 0 0 0}$ & 0,4073 & 1,1385 & 1,1314 & 0,4073 & 0,1126 \\
\hline QUALITY & 2,4551 & $\mathbf{1 , 0 0 0 0}$ & 6,2516 & 4,8556 & 5,1787 & 0,5135 \\
\hline DELIVERY & 0,8783 & 0,1600 & $\mathbf{1 , 0 0 0 0}$ & 3,2916 & 0,3840 & 0,1160 \\
\hline $\begin{array}{l}\text { LOCAL } \\
\text { CONTENT }\end{array}$ & 0,8839 & 0,2059 & 0,3038 & $\mathbf{1 , 0 0 0 0}$ & 0,7684 & 0,0833 \\
\hline ToT & 2,4551 & 0,1931 & 2,6044 & 1,3015 & $\mathbf{1 , 0 0 0 0}$ & 0,1747 \\
\hline
\end{tabular}

Source: Processed by Researchers, 2020.

The priority synthesis was carried out by the researcher as the next step according to the data in the pairwise comparison table of technical criteria, with the results in table 5.

\begin{tabular}{|l|l|}
\hline PRICE & 0.1126 \\
\hline QUALITY & 0.5135 \\
\hline DELIVERY & $\mathbf{0 . 1 1 6 0}$ \\
\hline $\begin{array}{l}\text { LOCAL } \\
\text { CONTENT }\end{array}$ & $\mathbf{0 . 0 8 3 3}$ \\
\hline TOT & $\mathbf{0 . 1 7 4 7}$ \\
\hline
\end{tabular}

After testing the consistency ratio (CR) on the overall pairwise comparison, the next step is to calculate the TPV for each alternative that will be prioritized. TPV is obtained from the comparative value between all criteria to prioritize the producing countries with the available alternatives, as shown in Table 6.

Table 6. TPV Technical Criteria

\begin{tabular}{|l|l|l|}
\hline Criteria & Alternative & Priority \\
\hline Price & Indonesia & 0,4688 \\
\hline & Countries in Europe & 0,2782 \\
\hline & Countries in Asia & 0,1360 \\
\hline \multirow{2}{*}{ Quality } & United States & 0,1170 \\
\hline & Indonesia & 0,3159 \\
\hline & Countries in Europe & 0,4269 \\
\hline \multirow{2}{*}{ Delivery } & Countries in Asia & 0,1000 \\
\hline & United States & 0,1571 \\
\hline & Indonesia & 0,4752 \\
\hline & Countries in Europe & 0,2412 \\
\hline \multirow{2}{*}{ Local Contents } & Countries in Asia & 0,1645 \\
\hline & United States & 0,1191 \\
\hline & Indonesia & 0,5867 \\
\cline { 2 - 3 } & Countries in Europe & 0,1908 \\
\hline
\end{tabular}




\begin{tabular}{|c|c|c|}
\hline & Countries in Asia & 0,1265 \\
\hline & United States & 0,0960 \\
\hline \multirow{4}{*}{$\begin{array}{l}\text { Transfer of } \\
\text { Technology }\end{array}$} & Indonesia & 0,3328 \\
\hline & Countries in Europe & 0,3516 \\
\hline & Countries in Asia & 0,1664 \\
\hline & United States & 0,1492 \\
\hline
\end{tabular}

After obtaining TPV, researchers then conducted a sensitivity analysis to determine variations in priority criteria to see the extent to which they affected priority alternatives. This sensitivity analysis is useful for maximizing the technical criteria that have a positive effect on the procurement of TNI's armaments. Table 7 shows the results of the sensitivity analysis criteria.

Table 7. Results of Hierarchy Process Analysis

\begin{tabular}{|c|c|c|c|c|c|c|c|c|c|}
\hline & Price & Quality & Delivery & Local Content & ToT & \multirow{5}{*}{$x$} & \multirow{4}{*}{$\begin{array}{l}0,11257 \\
0,51346 \\
0,11603 \\
0,08327 \\
\end{array}$} & \multirow{4}{*}{$=$} & \multirow{2}{*}{$\begin{array}{l}0,3771 \\
0,3558\end{array}$} \\
\hline Indonesia & 0,4688 & 0,3159 & 0,4752 & 0,5867 & 0,3328 & & & & \\
\hline Europe & 0,2782 & 0,4269 & 0,2412 & 0,1908 & 0,3516 & & & & 0,1254 \\
\hline Asia & 0,1360 & 0,1000 & 0,1645 & 0,1265 & 0,1664 & & & & 0,1417 \\
\hline USA & 0,1170 & 0,1571 & 0,1191 & 0,0960 & 0,1492 & & 0,17468 & & \\
\hline
\end{tabular}

\begin{tabular}{|l|r|}
\hline \multicolumn{1}{|c|}{ Alternatif } & \multicolumn{1}{|c|}{ Rank } \\
\hline Indonesia & 0,3771 \\
\hline Europe & 0,3558 \\
\hline Asia & $\mathbf{0 , 1 2 5 4}$ \\
\hline USA & $\mathbf{0 , 1 4 1 7}$ \\
\hline & \\
\hline
\end{tabular}

Source: Processed by Researchers, 2020.

V.

ANALYSIS RESULTS

Through data processing using the CADMID method in determining criteria and priority synthesis using the AHP method, 5 criteria are obtained from CADMID stages, namely price, quality, delivery, local content, and transfer of technology. Through data processing using the AHP method in the priority synthesis that produces TPV, researchers found that the quality technical criteria have the greatest weight value compared to other criteria, with details of quality $51.3 \%$, transfer of technology $17.5 \%$, delivery $11.6 \%$, price $11.3 \%$, and local content $8.3 \%$. Furthermore, researchers conducted a sensitivity analysis to look at the effect of the TPV value of the criteria on the TPV value which found that the assessment and consideration of the criteria would result in the priority of determining the country that made TNI's armaments, namely Domestic (Indonesia) of 37.71\%, Countries in Europe 35.58\%, United States 14.17\%, and Countries in East Asia 12.54\%.

\section{COMPARATIVE ANALYSIS OF AHP AND CADMID RESUlTS}

Starting from the description and results of data analysis, it appears that CADMID and AHP have a complementary relationship. It can also be interpreted that the criteria specified in the AHP are derivatives of CADMID elements. If CADMID contains a narrative aspect of an armaments procurement mechanism or in other words, CADMID is translated using a qualitative approach with an exploratory design analysis method, then AHP is a quantification process of CADMID by first determining the appropriate criteria. The survey was conducted to obtain the required data, then converted it into a measurement result that describes the phenomenon in numerical form. The process of determining the country of producing armaments can be synergized, where the criteria resulting from the considerations at the CADMID stage can be analyzed at the AHP method stage.

\section{CONCLUSION}

The results of CADMID analysis and data processing using the AHP method and sensitivity analysis to the effect of increasing the TPV technical criteria in all countries that manufacture TNI armaments show the results, namely Indonesia (Domestic) as the main 
priority for the making of the TNI's armaments compared to manufacturing countries in Europe, the United States and manufacturing countries in East Asia. Indonesia excels in the criteria of price, delivery, and local content, and ranks second in quality and technology transfer.

This study proves that the CADMID and AHP methods can be synergized to determine priority alternatives for the selection of the country for the manufacture of TNI's armaments. The selection of a good and appropriate manufacturing country will minimize the existing risks, which can properly support consistency, sustainability, and interoperability in supporting Indonesia's defence strategy.

\section{REFERENCES}

[1] Punch, K. F. (1998), Qualitative Research Method: Grounded Theory. International Journal of Business and Management, Vol. 9, No. 11, 2014.

[2] Samadi M and Hasan M, Implementation of The Concept and Theory of Management Functions in Efforts to Improve Quality, International Journal of Economic, Business and Accounting Research (IJEBAR), Volume-Issue 2, 2020 (IJEBAR), 2020

[3] Setiawan, Arifin, Wiedo Ananto, and Totok Soehartanto. (2020). Implementasi Metode Analytic Hierarchy Process dalam Pemilihan Radar Udara 3D. Rekayasa. 2020; 13(1): 49-54, 2020. Retrieved from DOI: https://doi.org/10.21107/rekayasa.v13i1.6778, accessed on 7 November 2020.

[4] Susilo, Iwan Hendra, Amarulla Octavian, and Udisubakti Ciptomulyono. (2019). Application of MCDM - AHP and BCA Methods - Diplomacy Aspect for Warship's Determination on MTF - UNIFIL Mission. International Journal of Technology. 2019.

[5] Zala, Benjamin. (2015), Strategy in an Era of Rising Powers. The RUSI Journal, in Dejan Stojković and Blažo M. Radović. (2017), Strategic Environment Influence on Development of Defence of the Republic of Serbia, Vojno Delo, 4/2017.

Books

[6] Bhushan, Navneet dan Kanwal Rai. Strategic Decision Making; Applying the Analytic Hierarchy Process. London: Springer, 1966.

[7] Crown, The Acquisition Handbook, Tactica Solutions Limited, 2002. Edition 4 January 2002

[8] United States Department of Defence Fiscal Year 2020 Budget Request. Program Acquisition Cost by Weapon System.

\section{AUTHORS}

First Author - Rujito Dibyo Asmoro, Indonesia Defence University, rujito.asmoro@idu.ac.id Second Author - Suharto, Indonesia Defence University, suharto_ladjide@tnial.mil.id Third Author - Mitro Prihantoro, Indonesia Defence University, mitro.prihantoro@idu.ac.id Fourth Author - Cecep Hidayat, Indonesia Defence University, cecephidayat.idu @ gmail.com Fifth Author - Purnomo Yusgiantoro, Indonesia Defence University 